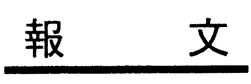

\title{
ヨウ素を増感剂としたリノレン酸メチルの光共役化反応
}

\author{
関 桂・金子良平・五月女武雄・関口 董 \\ 宇都宮大学工学部応用化学科 ( $\bar{T} 321$ 宇都宮市石井町 2753)

\section{Photoconjugation of Methyl Linolenate in the Presence of Iodine as a Sensitizer}

\author{
Katsura Seki, Ryohei K^neko, Takeo S^otome, and Kaoru Sekiguchi \\ Department of Applied Chemistry, Faculty of Engineering, Utsunomiya University \\ (2753, Ishii-cho, Utsunomiya-shi, $\bar{\top} 321$ )
}

In the previous paper, we reported the optimum conditions for the iodine-sensitized conjugation of methyl linoleate and its reaction mechanism.

This paper discusses isomerization arising from irradiation with a $100 \mathrm{~W}$ high-pressure mercury lamp using methyl linolenate with a 1,4,7-triene structure. Conjugated diene-trienoates and small amounts of conjugated trienoates are formed in this reaction. Slightly milder conditions than in methyl linoleate are suitable for the formation of conjugated diene-trienoates. The reaction conducted at room temperature using a sample with a concentration of 10 to $20 \%$ adding approximately $0.1 \%$ of iodine to a nonpolar solvent such as petroleum ether by irradiation for 4 $\sim 6 \mathrm{~h}$ is considered optimum. To obtain conjugated trienoates mainly, however, milder conditions such as no more than $0.03 \%$ iodine should be used. Under such conditions, the amounts of conjugated compounds were as much as about $70 \%$ (conjugated diene-trienoates 55 62\%; conjugated trienoates $8 \sim 15 \%$ ) of the reaction products.

This sensitized isomerization proceeds in the same way as indicated in the previous report and double bonds shift only in the direction of the conjugation.

\section{1 緒 言}

先に著者ら ${ }^{1) 2}$ は, 1,4 -ジエン構造を持つリノール 酸メチルのヨウ素增感反応について検討し, その最適条 件並びに共役化機構について明らかにした。必須脂肪酸 の一つであり，1,4-ジェンをさらに累積した 1,4,7-ト リエン構造を持つリノレン酸メチルのヨウ素増感異性化 には興味深いものがある。リノレン酸メチルの共役化に ついては水酸化アルカリ ${ }^{3)}$, カリウム $t$-ブトキシド4 などを触媒とした報告があり，これらの場合は共役ジエ ン系及び共役トリエン系を持つオクタデカトリエン酸メ チル(以下それぞれ共役ジエン及び共役トリエンと略記) に移行するが，シス，トランス型の共役ジエンが主体で ある。そこで今回,リノレン酸メチルを試料として用い, 水銀灯照射下におけるヨウ素増感異性化反応を明らかに すると共に，その反応条件を検討した。

\section{2 実 験}

\section{$2 \cdot 1$ 機器分析}

$\mathrm{GC}$, 熱分解 $\mathrm{GC}, \mathrm{IR}$ 及び $\mathrm{UV}$ は前報 ${ }^{2)}$ と同様に測定 した。

\section{$2 \cdot 2$ リノレン酸メチルの製取}

あまに油混合脂肪酸を尿素付加分別法で処理し，その 母液部からイソプロピルエーテル不溶性六臭化物 $(\mathrm{mp}$ $\left.180 \sim 181^{\circ} \mathrm{C}\right)$ を得た。次にこれを脱臭素, エステル化し た後, 精留によりリノレン酸メチルを製取した。bp 160 $\sim 168^{\circ} \mathrm{C} / 2 \mathrm{mmHg}, d_{1}^{20} 0.8997, n_{\mathrm{D}}^{20} 1.4713$, け九化価 191.3 , ヨウ素価 260.1 , 純度 $99.0 \%$ 。

$2 \cdot 3$ リノレン酸メチルのヨウ素增感異性化反応

使用した $100 \mathrm{~W}$ 内部照射型高圧水銀灯装置（ウシオ 電機製 UM-102 型) 及び実験方法は前報 ${ }^{2)}$ と同様であ り, 反応は Fig. -4 を除きすべて $30^{\circ} \mathrm{C} て ゙$ 行った。反応 溶液を適宜採取し所定の処理を行い, その $n_{\mathrm{D}}, \mathrm{UV}$, 
GC, IR，TLCにより反応追跡すると共に，生成物中の 共役ジエン及び共役トリエン含量を UV から算出 ${ }^{5)} し$ た。

反応溶媒はそれぞれ所定の精製を行い，石油エーテル は bp $40 \sim 60^{\circ} \mathrm{C}$ の留分を使用した。

\section{$2 \cdot 4$ 共役オクタデカトリエン酸の分画}

$2 \cdot 3$ によって得られた生成物を加水分解した後,一その 脂肪酸を石油エーテルから再結晶して無色板状晶 $(\mathrm{mp}$ $72 \sim 73^{\circ} \mathrm{C}$ ) の共役オクタデカトリエン酸を分画した。ま たこの母液部から尿素付加分別法及び再結晶を繰り返し て, 4 種の共役ジエン酸部を濃縮した。

\section{$2 \cdot 5$ 反応生成物のオゾン分解}

$2 \cdot 3$ の反応生成物及び 2.4 で分画した共役トリエンに ついて前報 ${ }^{2)}$ と同様にオゾン化し，得られたオゾニドを 熱分解 GCにより分析した。

\section{3 結果と考察}

\section{$3 \cdot 1 \exists ウ$ 素增感共役化の最適条件}

前報2)において, ヨウ素は溶媒の種類や温度の違いに よりその色相を異にし，これがヨウ素の溶存状態上密接 に関係することを述べた。ヨウ素を石油エーテル，ベン ゼンあるいはエ夕ノールなどに溶解すると,それぞれ紫, 赤紫あるいは褐色の 3 種の色相を呈する。これらの溶液 に試料のリノレン酸メチルを添加したところ, リノール 酸メチルの場合とほぼ同じ電子スペクトルを示した。す なわち後者 2 種の溶液には試料添加の影響はほとんど認 められなかった。しかし石油エーテルの場合には, 溶液 の色相も紫色から赤紫色を呈し，スペクトル的にもわず かながら可視領域 $(\lambda \max 522 \mathrm{~nm})$ のブルーシフトが認 められた。

これらの点を踏まえ，まず $1,4-$ 泣エン系の比較をか ね、ヨウ素増感反応に及ぼす溶媒の影響を検討した。そ の結果 Fig. -1 に示した様に, 前報 ${ }^{2)}$ とほぼ類似した傾 向が認められた。試料濃度 $10 \%$,増感剂 $0.1 \%$, 反応温 度 $30^{\circ} \mathrm{C}$ においては, 石油エーテルの場合に最も共役シ エン化が進み， $4 \mathrm{~h}$ で約 $60 \%$ の平衡に達した。しかし 共役トリエンはそ机より短時間 ( $2 \mathrm{~h}$ 程度) で約 $10 \%$ に 達した後, 時間と共に減少する傾向を示した。ベンゼン では共役化が速やかに進行し，共役トリエン生成量も良 好であったが，共役ジェンの平衡值は多少低下した。な おリノール酸メチルの場合之同様, 照射波長領域に溶媒 自身の吸収を持つ二硫化炭素では反応が遅れ，アセトン ではエタノールと同样，増感共役化がほとんよ゙進行しな かった。四塩化炭素の場合には，反応中塩化水素の発生 を伴い，塩化水素付加物並びに重合物の生成も認められ た。

この様に反応溶媒としては, ヨウ素を分子状で溶解し, またそれ自身が $300 \mathrm{~nm}$ より長波長に吸収帯を示さない

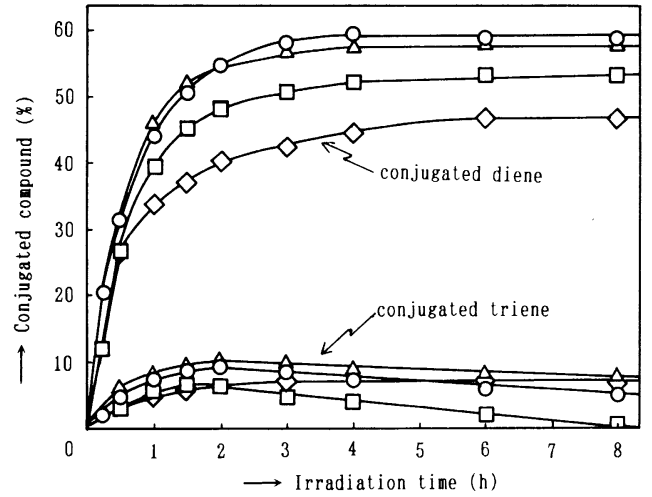

Fat concentration: $\quad 10 \%$ Iodine concentration: $\quad 0.1 \%$ Solvent:

-O- Petroleum ether, $-\triangle-$ Benzene, $-\square-$ Carbon tetrachloride, $-\diamond-$ Carbon disulfide

Fig. -1 Effect of solvent on photoconjugation process of methyl linolenate with iodinesensitizer at $30^{\circ} \mathrm{C}$.

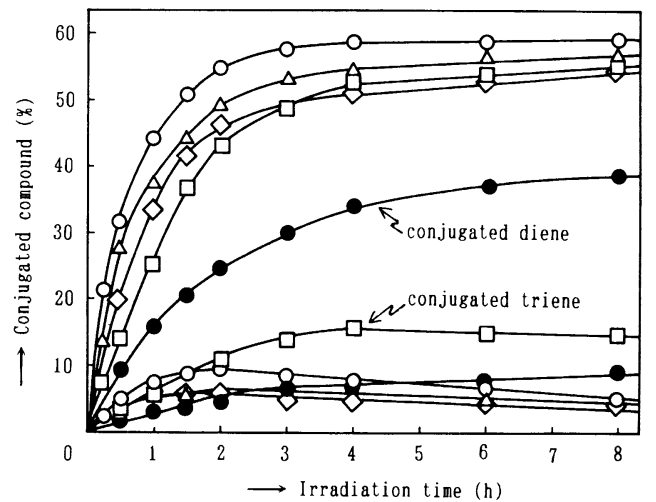

Pat concentration: $\quad 10 \%$ Solvent: Petroleum ether Iodine concentration:

$0.01 \%,-\square-0.03 \%,-\mathrm{O}-0.1 \%,-\triangle-0.2 \%,-\diamond-0.3 \%$

Fig. -2 Effect of iodine concentration on photoconjugation process of methyl linolenate with iodine-sensitizer at $30^{\circ} \mathrm{C}$.

炭化水素系のものが最適と考えられる。

そこで，以下の実験ではすべて石油エーテルを用い， 次にヨウ素量について検討した。すなわち試料の $10 \%$ 溶液に，增感剤を 0.01 0.3\% 添加して異性化を行った (Fig. - 2)。ヨウ素濃度の低い範囲では, 共役ジエン生 成量は添加量の増加に伴って急速に増大し $0.1 \%$ で最高 になり，それより高濃度ではむしろ減少傾向が見られた。 こ㧈に対し共役トリエン生成量は, $0.03 \%$ 添加時に最大 


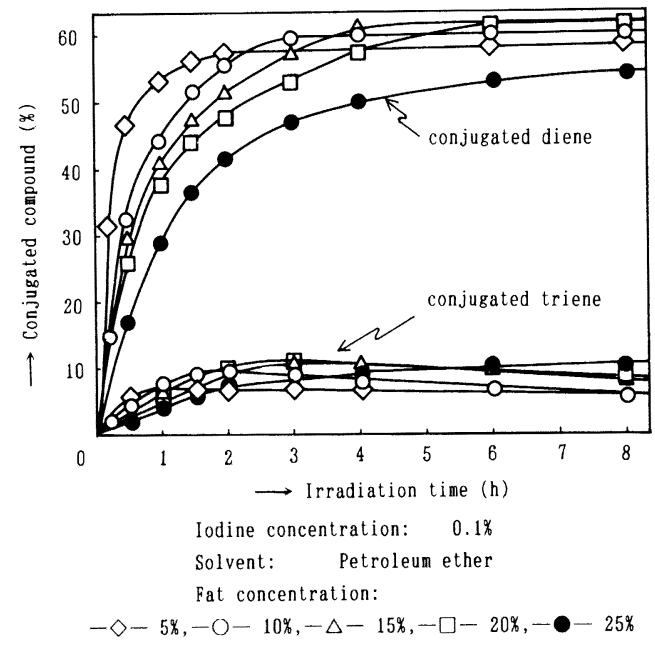

Fig. -3 Effect of fat concentration on photoconjugation process of methyl linolenate with iodine-sensitizer at $30^{\circ} \mathrm{C}$.

値 (約 15\%) を示し，さらに長時間照射すれば共役ジエ ンも最大平衡に達するものと考えられた。

次にヨウ素を $0.1 \%$ 添加した際の試料濃度の影響を調 べた。Fig.ー3から明らかな様に, 低濃度すなわち試料 に対するヨウ素の比率が大きいもの程反応が速やかに進 行して共役ジェンは短時間で平衡に達したが, 共役トリ エン生成量はむしろ低下した。すなわち試料濃度 $5 \%, 10$ \%では共役ジエン及び共役トリエン生成量は, それぞ れ $2 \mathrm{~h}, 3 \mathrm{~h}$ 及び $40 \mathrm{~min}, 1.5 \mathrm{~h}$ で最高になるが, その後 共役トリエンは重合物へ移行する様である。試料 15 $20 \%$ では共役ジエンが平衡に達するのに $6 \mathrm{~h}$ 程度を要 したが，反応が温和になるため最終的な生成量は $62 \%$ に達した。 $25 \%$ では共役ジエン生成が遅くなったが, 共役卜リエンに関しては比較的良好であった。

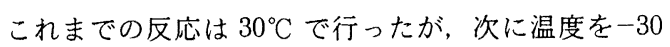
$\sim 40^{\circ} \mathrm{C}$ と変えてその影響を検討した (Fig. -4$)$ 。やはり $-30^{\circ} \mathrm{C}$ では二ヨウ化物の生成が優先するためか共役化は ほとんど進行しなかった。 $10^{\circ} \mathrm{C}$ から $40^{\circ} \mathrm{C}$ となるに従い 共役化生成物は急激に増加した。一方共役トリエンは $10^{\circ} \mathrm{C}$ において $8 \mathrm{~h}$ でも増加傾向にあるのに対し，30 $40^{\circ} \mathrm{C}$ では $2 \mathrm{~h}$ 付近をさかいにして不溶性重合物の副生 を伴いわずかながら減少した。

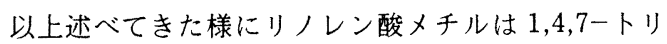
エン構造であるため, リノール酸メチルに比べ反応が複 雑になったが, 主生成物として共役ジエンと少量の共役 トリエンが得られた。また TLCによると共役生成物の 二量化や重合による副生成物も認められた。この共役ジ エン生成については先のリノール酸メチル2) の場合より やや温和な条件が適切であり, 石油エーテル, ヘキサン

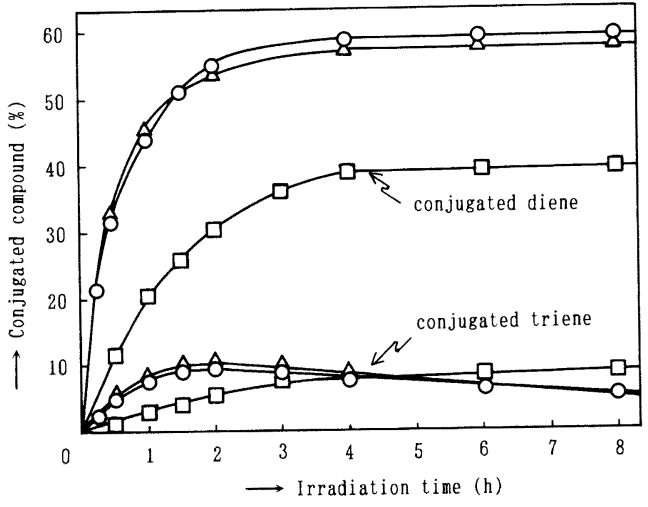

Pat concentration: $\quad 10 \%$ Iodine concentration: $\quad 0.1 \%$ Solvent: Petroleum ether Temperature:

$-\square-10^{\circ} \mathrm{C},-\mathrm{O}-30^{\circ} \mathrm{C},-\triangle-40^{\circ} \mathrm{C}$

Fig. -4 Effect of temperature on photoconjugation process of methyl linolenate with iodinesensitizer.

やベンゼンなどの無極性溶媒下で, $0.1 \%$ 程度のヨウ素 を添加し, 試料濃度を $10 \sim 20 \%$, 常温で 4 6 h 光照射 するのが適当と考えられる。一方共役トリエンに関して は, ヨウ素添加量を $0.03 \%$ 程度におさえた温和な条件 下で行うのが望ましい。この様な条件下では，共役化生 成物はいずれも約 70\%（共役ジエン 55〜62\%, 共役トリ エン 8〜15\%) に達した。

\section{2 反応生成物}

反応生成物の IR において, $990 \mathrm{~cm}^{-1}$ 及び $950 \mathrm{~cm}^{-1}$ 付近にそれぞれ trans, trans-共役体の生成を示す強い 吸収之 cis, trans-共役ジエンによる弱い吸収が現れ， その他 $965 \mathrm{~cm}^{-1}$ にトランス孤立二重結合による微弱な 吸収が見られた。この様に生成物の共役ジエン及び共役 トリエン系は全トランスのものが主体であった。

また生成物の GC は非常に複雑であり, 微量のモ) エンとジェン，それに連なる著量の共役ジエンのピーク 群が, 最後に $\alpha$ 一及び $\beta$-エレオステアリン酸メチルの 保持時間とほぼ一致する共役トリエンのピークが現れ た。この共役トリエンのうち, 多量生成物であり保持時 間の大きいものを分画した。その IR, GC, UV またオ ゾニドの熱分解 GC によりブタナールと10ーオキソデ カン酸メチルを検出したことなどから, trans-10, trans -12, trans-14-オクタデカトリエン酸メチルと同定さ れ, 少量成分はそのモノシス体と推定された。主生成物 である共役ジエンは $\mathrm{GC}$ 的に 4 種生成し, はじめの 2 ピークは $948 \mathrm{~cm}^{-1}$ に吸収を持ち cis, trans-共役ジエ ン体であり, 保持時間の大きい 3,4 番目のピークは 990 $\mathrm{cm}^{-1}$ に強い吸収を示し trans, trans-共役ジエン体之 


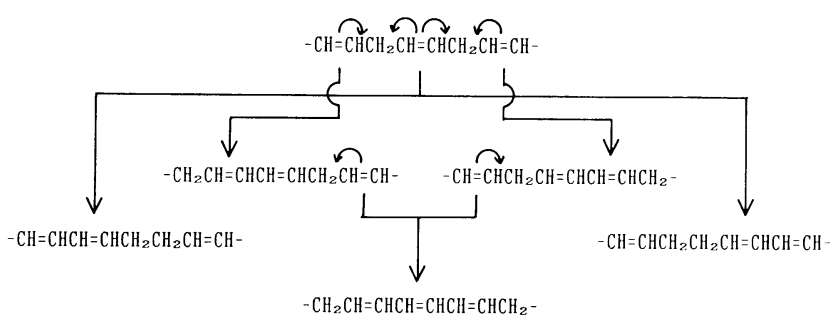

Fig. -5 Photoconjugation path of methyl linolenate in the presence of iodine as a sensitizer.

\section{考えられた。}

\section{$3 \cdot 3$ 反応機構}

以上の事実之前報 ${ }^{2)}$ で述べたこの反応の特徴を考慮す ると, 増感異性化反応の機構は次の様に考察される。ヨ ウ素はリノレン酸メチルの二重結合と $\pi$ 錯体を形成する が，これは非常に不安定であり， $\sigma$ 錯体へ移行すること なく光により容易にヨウ素を再解離する。従って, まず 可視光線 (特に 436, 546 及び 577 579 nm) により解離 したヨウ素原子がリノレン酸メチルの二重結合を攻撃 し, 橋かけ構造のヨードアルキルラジカルを形成する。 それから $2 つ の$ 経路に分かれ，これにヨウ素がトランス 付加すると二ヨウ素付加物を生成し，また水素移動を伴 うとより安定な共役ラジカルへ移行する。前者は初期段 階では生成するが室温では不安定であるため, 時間と共 に後者に移行する。次いで後者からヨウ素原子が脱離し て共役化が進行するわけであるが，その際幾何異性化を 伴って安定なトランス体が主成分となる。

ヨウ素原子のリノレン酸メチルへの攻撃には, 中央と 両端の二重結合の 3 個所がある。Fig. -5 に示した様に, 中央の二重結合に付加が起こると，9，11，15-及び 9, 13，15一共役ジエンを生成する。これらは二重結合間に 2 個のメチレンを有するためこれ以上反応は進まず，共 役系の幾何異性化のみが進行する。一方, 両端すなわち 9 及び 15 位二重結合への攻撃では $10,12,15$-及び 9 , 12，14一共役ジエンを経た後，10，12，14一共役トリエン まで移行する。この様に生成した共役化物はさらにヨウ
素増感幾何異性化を受け，最終的に全トランス共役系を 主体とする生成物を与える。

また増感異性化生成物につき，そのオゾ二ドの熱分解 GC を行ったところ，プロパナールとブタナール並びに 9-オキソノナン酸メチルと10-オキソデカン酸メチル が検出された。この事実からも二重結合の移動は共役化 の方向にのみ進行することが明らかである。

先に述べた様に, この異性化では共役トリエンが共役ジ エンより速やかに平衡に達し，その後減少傾向を示した。 これは恐らくいったん生成した共役トリエンの一部が Diels-Alder 型の二量体や不溶性多量体へ移行するため と考元られる。また前報 ${ }^{2)}$ 之同様, この反応でも不均化に よるオクタデカジエン酸メチルの生成が多少認められた。

終わりに，本研究の実験に御協力いただいた小松久人 氏に謝意を表します。〔平成元年 (1989) 5 月 12 日受理〕

1）金子良平, 関 桂, 小宮山勝志, 近喰秀男, 日化, 91, 1193 (1970)

2）関桂, 金子良平, 小林克夫, 油化学, 38, 949 (1989)

3) J.C. Crowan, Ind. Eng. Chem., 41, 294 (1949); B.A. Brice, M.L. Swain, S.F. Herb, P.L. Nicols Jr., R.W. Riemenschneider, J. Am. Oil Chem. Soc., 29, 279 (1952)

4) J. Ugelstadt, B.J. Jenssen, P.C. Mörk, Acta Chem. Scand., 16, 323 (1962); 高木 徹, 福住一雄, 南谷晴子, 油化学, 18, 193 (1969)

5）日本油化学協会編, “基準油脂分析試験法”，(1971）2.4. $15-71$

\section{国際油脂情報}

[Cocomunity 31, Oct. 1989 吉富和彦]

$\star I T C ，$ 油糧種子・油脂販売者の手引発行へ

ITC の代表 Mrs. M. Maftei 氏は油糧種子・油脂販売者の手引を発行する予定である。本刊行物は 2 冊分か ら成り, 主要植物油の取引に関するを網羅している。発行後 ITCは世界の油糧取引業界にこれを導入するため, セミナーを行う計画である。

\section{৯アキノ大統領，ココナッッ促進のため訪米}

フィリピンのアキノ大統領の訪米日程には, スミソニアン博物館の訪問, 優れた科学者等に対する演説及び Byrd 展示場で開催のフィリピン天然産物展示会の訪問が含まれている。展示会で目立つものにココナッッの樹 がある。本展示会の資料提供, パンフレットや“ココナッッは天然物であり，健康によい”とのメッセージを揭 載した印刷物の提供には, UCAP (フィリピン・ココナッツ協会連盟) が協賛し，ココナッツ産業界を支持する。 